\title{
Summer microhabitat use and overlap by the invasive Round Goby (Neogobius melanostomus) and native darters in the Trent River (Ontario, Canada)
}

\author{
Scott M. Reid* \\ Aquatic Research and Monitoring Section, Ontario Ministry of Natural Resources and Forestry, Trent University - DNA Building, \\ 1600 West Bank Drive, Peterborough, Ontario K9L 0G2, Canada
}

Received: 27 February 2019 / Accepted: 1 May 2019

\begin{abstract}
Understanding the impacts of the invasive Round Goby (Neogobius melanostomus) is important for North American native fish conservation. One proposed mechanism for native species declines is competition for habitat. In this study, summer habitat use by Round Goby and Channel Darter (Percina copelandi) and Logperch (P. caprodes) was studied in the Trent River (Canada). Spotelectrofishing and systematic habitat sampling were used to measure habitat availability and use. Suitability for all species varied across the range of habitat conditions. At Glen Ross, habitat suitability for Channel Darter and Round Goby was highest at intermediate water depths $(0.2-0.6 \mathrm{~m})$, lowest at high water velocities $\left(>1.0 \mathrm{~ms}^{-1}\right)$ and increased with greater amounts of gravel and cobble. There were no significance habitat differences between capture locations of the two species. At Meyer's Reach, Logperch and Round Goby habitat suitability was highest at intermediate water depths $(0.4-0.6 \mathrm{~m})$ and where gravel and cobble were abundant. The relationship between suitability and water velocity differed between species, with moderate velocities less suitable for Round Goby. The amount of boulder and bedrock at capture locations of each species differed. Results indicate that competition for habitat with Round Goby will vary among darter species.
\end{abstract}

Keywords: habitat / invasive species / competition / fishes / river

Résumé - Utilisation et chevauchement des microhabitats d'été par le gobie à taches noires (Neogobius melanostomus) et les darters indigènes dans la rivière Trent (Ontario, Canada). Comprendre les impacts du gobie à taches noires (Neogobius melanostomus) est important pour la conservation des poissons indigènes d'Amérique du Nord. L'un des mécanismes proposés pour le déclin des espèces indigènes est la concurrence pour l'habitat. Dans cette étude, l'utilisation de l'habitat d'été par le gobie à taches noires et deux darters indigènes, le fouille-roche gris (Percina copelandi) et la perche noire $(P$. caprodes) a été étudiée dans la rivière Trent (Canada). La pêche ponctuelle à l'électricité et l'échantillonnage systématique de l'habitat ont été utilisés pour mesurer la disponibilité et l'utilisation de l'habitat. La pertinence pour toutes les espèces variait selon les conditions de l'habitat. A Glen Ross, la qualité de l'habitat $\mathrm{du}$ fouille-roche gris et du gobie à taches noires était la plus élevée aux profondeurs intermédiaires $(0,2-$ $0,6 \mathrm{~m})$, la plus faible aux vitesses élevées $\left(>1,0 \mathrm{~ms}^{-1}\right)$ et augmentait avec des quantités supérieures de gravier et de galets. Il n'y avait pas de différences importantes entre les habitats des deux espèces entre les lieux de capture. À Meyer's Reach, la qualité de l'habitat de la perche noire et du gobie à taches noires était la plus élevée aux profondeurs d'eau intermédiaires $(0,4-0,6 \mathrm{~m})$ et là où le gravier et les galets étaient abondants. La relation entre l'adéquation et la vitesse de l'eau différait d'une espèce à l'autre, les vitesses modérées étant moins adaptées au gobie à taches noires. La quantité de blocs rocheux et de substratum rocheux aux lieux de capture de chaque espèce différait. Les résultats indiquent que la concurrence pour l'habitat du gobie à taches noires variera selon les espèces de darter.

Mots clés : habitat / espèces envahissantes / compétition / poissons / rivière

\footnotetext{
*Corresponding author: reid.scott@ontario.ca
} 


\section{Introduction}

The Round Goby (Neogobius melanstomus Pallas, 1814) is a small-bodied, benthivorous fish of Eurasian origin. The species was first detected in North America in 1990 from the St. Clair River (Jude et al., 1992); which connects Lake Huron to Lake St. Clair. Round Goby was likely introduced to North America from ballast water discharged from transatlantic ships originating from Eastern Europe. Within five years, the species had spread to all five of the Laurentian Great Lakes (Charlebois et al., 2001). Round Goby is an aggressive, rapidly colonizing, invasive fish that disrupts spawning of other benthic fishes and may eat the eggs and fry of native fishes (Kornis et al., 2012). In parts of the Great Lakes, the species has been implicated in the decline of small, native benthic fishes such as the Channel Darter (Percina copelandi Jordan, 1877), Johnny Darter (Etheostoma nigrum Rafinesque, 1820), Logperch (P. caprodes Rafinesque, 1818), and Mottled Sculpin (Cottus bairdii Girard, 1850) (Janssen and Jude, 2001; Thomas and Haas, 2001; Reid and Mandrak, 2008). While present in the Great Lakes for more than 25 years, the secondary invasion upstream of Round Goby into Ontario streams and rivers has been a more recent occurrence (Poos et al., 2010; Raby et al., 2010; Raab et al., 2018). Subsequent research in Great Lakes tributaries has identified that habitat and dietary competition between Round Goby and native darters is likely occurring (Abbett et al., 2013) and, in some watercourses, the distribution and abundance of small native fishes are negatively associated with Round Goby presence and abundance (Krakowiak and Pennuto, 2008; Abbett et al., 2013; Kornis et al., 2013; Raab et al., 2018).

In 2003, Round Goby was first collected from the Trent River downstream of the Lock 18 dam in the town of Hastings, Ontario (Canada) (Gutowsky and Fox, 2011). The Trent River forms part of the $386 \mathrm{~km}$ long Trent-Severn Waterway (National Historic Site of Canada) that connects Georgian Bay (Lake Huron) to Lake Ontario. The introduction is believed to be the result of anglers using baitfish collected from goby-infested waters in Lake Ontario. At the time of the discovery, Round Goby was also abundant in the Bay of Quinte (Lake Ontario), where the Trent River flows into (Taraborelli et al., 2009). An abundance of suitable Round Goby habitat (areas with cobble and boulder-sized bed material) is present along the Trent River, and the species' downstream and upstream expansion throughout the river was rapid (Raby et al., 2010) and complete by 2010 (Reid, unpublished data). Beyond Lock 18, Round Goby has spread more than $60 \mathrm{~km}$ upstream along the Otonabee River to the City of Peterborough (EDDMapS, 2019).

Seven native, small-bodied, benthic fishes are present along the Trent River: Central Stoneroller (Campostoma anomalum Rafinesque, 1820), Channel Darter, Fantail Darter (E. flabellare Rafinesque, 1819), Johnny Darter, Logperch, Longnose Dace (Rhinichthys cataractae Valenciennes, 1842), and Stonecat Madtom (Noturus flavus Rafinesque, 1818). Of these species, the Channel Darter is listed as Endangered under the Federal Species at Risk Act (SARA). Invasive species are considered a significant threat affecting Canadian freshwater fishes at risk (Dextrase and Mandrak, 2006). For imperiled darters, the risk of adverse population impacts due to Round

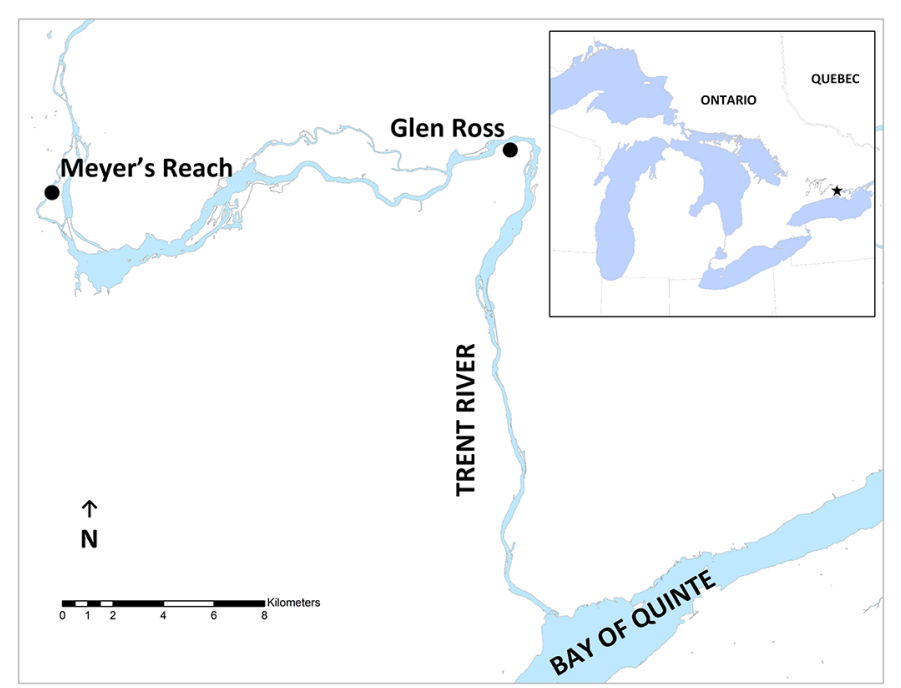

Fig. 1. Location of the two study sites along the Trent River, and the study area within the Laurentian Great Lakes basin (inset map).

Goby invasions has been assessed as high (DFO, 2011; COSEWIC, 2016). However, these assessments were largely based on expert opinion and, therefore require validation through field research and monitoring. One of the proposed mechanisms associated with negative Round Goby impacts is competition for habitat and shelter (Balshine et al., 2005; Abbett et al., 2013). In this study, summer microhabitat use by Round Goby and two darter species (Channel Darter and Logperch) was characterized at wadeable Trent River sites, and the magnitude of habitat overlap assessed.

\section{Materials and methods}

\subsection{Data collection}

Over the period of September 5th and 21st, 2017, daytime (9:00 am to $17: 00 \mathrm{pm}$ ) microhabitat use was studied at two Trent River sites: Channel Darter and Round Goby habitat use at Glen Ross $\left(44^{\circ} 15^{\prime} 47^{\prime} \mathrm{N} ; 77^{\circ} 35^{\prime} 49^{\prime} \mathrm{W}\right)$ and, Logperch and Round Goby habitat use at Meyer's Reach $\left(44^{\circ} 15^{\prime} 18^{\prime} \mathrm{N}\right.$; $77^{\circ} 48^{\prime} 43^{\prime} \mathrm{W}^{\circ}$ ) (Fig. 1). Both sites are located downstream of Lock 18. Sites were selected based on suitability of habitats for sampling (i.e. electrofishing could be safely undertaken by foot) and the abundance of native darters. Channel Darter and Logperch have been collected at other Trent River sites, but the numbers of each species were considered too low for a robust study of habitat use (Reid, 2004, 2006). Wetted channel widths were between 37 and $100 \mathrm{~m}$ at the Meyer's Reach site, and between 145 and $179 \mathrm{~m}$ at the Glen Ross site. The mean river flow rate was $64.9 \mathrm{~m}^{3} / \mathrm{s}$. Water temperatures during sampling ranged from 15.1 to $22.8^{\circ} \mathrm{C}$. Sampling occurred over seven days at Glen Ross and six days at Meyer's Reach.

A spot-sample electrofishing technique was used to collect darters and Round Goby and characterize habitat use (Johnson, 2008; Abbett et al., 2013). Electrofishing was limited to those wadeable habitats that could be safely and effectively sampled (water depths $<1 \mathrm{~m}$ ). The area of habitat sampled was approximately $13000 \mathrm{~m}^{2}$ at Glen Ross (within $40 \mathrm{~m}$ of the riverbank), and $20000 \mathrm{~m}^{2}$ at Meyer's Reach (across the entire 
channel width). Fishes were collected by a 2-person crew using a Smith-Root 12B backpack electrofishing unit (settings: $400 \mathrm{v}$ ). Darter and goby collection points were individually marked with coloured, flat metal rings (i.e. a washer). Markers were placed by hand at locations where individual fishes were visually observed to be first stunned by the electrical field. Captured fishes were measured for total length (TL) on a measuring board after sampling was complete. All fishes were released after measurement.

A systematic transect sampling approach was used to describe habitat availability (Simonson, 1993). At each site, habitat characteristics were measured at points systematically distributed across the area of habitat electro-fished. Multiple transects were placed parallel to the shoreline and evenly distributed across the river. Transects (and sampling points) were demarcated with an anchored $68 \mathrm{~m}$ length of rope with white floats every four metres. Habitat availability was characterized at a total of 800 points in the area sampled at Glen Ross, and at a total of 500 points in the area sampled at Meyer's Reach. With this study design, individual resource use is characterized but availability is measured at a population level (Manly et al., 2002).

Physical habitat measurements taken at each point included water depth $(\mathrm{m})$, mid-water column velocity $\left(\mathrm{ms}^{-1}\right)$ and bed material composition (visual assessment of percent bedrock, boulder, cobble and gravel). Habitat characteristics common to other riverine fish-habitat studies (e.g. woody debris, aquatic vegetation, and fine sediment) were rare or absent, and therefore not measured. Water depth and water velocity were measured with a top-setting wading rod and a Swoffer ${ }^{\mathrm{TM}}$ water velocity meter. Water velocity was measured at 0.6 of the water depth (Bain and Stevenson, 1999). Visual-based (i.e., snorkelling) studies of stream fish microhabitat selection often include estimates of focal point elevation (vertical distance of the fish from the bottom) and focal point water velocity (velocity at the fish's snout) (Leidy, 1992). For benthic fishes, focal point water velocities can be expected to be less than mean water column velocity (as measured at 0.6 of depth) (Stauffer et al., 1996; Welsh and Perry, 1998). Darter and Round Goby focal point elevations could not be estimated using electrofishing-based collections. For this study, mean water column velocity is assumed to be an index of focal point velocity. Percent composition of bed material was visual assessed using the following modified Wentworth particle size categories: bedrock, boulder (>256 mm diameter), cobble $(65-256 \mathrm{~mm})$, and gravel (2$64 \mathrm{~mm})$.

\subsection{Data analysis}

For each species, habitat suitability curves were developed individually for (i) water depth, (ii) water velocity, and (iii) combined percentage of gravel and cobble bed material. Curves were generated following the approach described by Hightower et al. (2012). The probability of using habitat category $i$ was modeled as:

$$
P_{i}=\frac{w_{i} a_{i}}{\sum_{j=1}^{n}\left(w_{j} a_{j}\right)}
$$

where $a_{i}$ is the proportion of habitat available in category $i$, and $w_{i}$ is the unscaled relative probability of using habitat $i$ based on the frequency of each species in habitat $i$ if all habitats were equally available. Estimates of $w_{i}$ would be similar in magnitude if all habitats were used in proportion to their availability. As per Hightower et al. (2012), w $w_{i}$ values were rescaled to a maximum of 1 for all habitat variables.

Principal component analysis (PCA) was used to visualize, in multivariate space, the similarity of habitat use by native darters and Round Goby, with reference to available habitat. As variables were measured with different units, variables were standardized by subtracting the mean and dividing by the standard deviation (Legendre and Legendre, 1998). Principal components (PC) with eigenvalues greater than 1 and loadings greater than $|0.6|$ were retained. PC scores were subsequently used as dependent variables in Multivariate Analysis of Variance (MANOVA) to test for habitat differences between darters and Round Goby, and between collection points and available habitat. Hotelling's $\mathrm{T}^{2}$ was used to test for pairwise differences, and $p$-values were adjusted using a sequential Bonferoni correction. Statistical analysis was completed using PAST version 1.94 (Hammer et al., 2001).

\section{Results}

One hundred-nineteen Channel Darter, 421 Logperch and 360 Round Goby were captured during electrofishing. The median (range, standard deviation) total length of Channel Darter was $61.5(52-70,3.6) \mathrm{mm}$, of Logperch was 106 $(61-140,12.8) \mathrm{mm}$, and of Round Goby was 83 (29-168) $\mathrm{mm}$. Round Goby collected from Glen Ross (median: $81 \mathrm{~mm}$; range: 29-168; standard deviation: 21.3) and Meyer's Reach (median: $86 \mathrm{~mm}$; range: 40-134; standard deviation: 24.9) were of similar size. Other species commonly encountered during electrofishing include Longnose Dace, Pumpkinseed (Lepomis gibbosus Linnaeus, 1758), Rock Bass (Ambloplites rupestris Rafinesque, 1817), and Smallmouth Bass (Micropterus dolemieu Lacépède, 1802). Glen Ross flow conditions were characterized by moderate water depths $(0.4-0.8 \mathrm{~m})$ and water velocities typically below $0.6 \mathrm{~ms}^{-1}$. Along Meyer's Reach, water depths were generally shallow $(<0.4 \mathrm{~m})$ with water velocities less than $0.3 \mathrm{~ms}^{-1}$. The Glen Ross riverbed was a relatively even mix of gravel, cobble, boulder and bedrock. Riverbed material along Meyer's Reach was dominated by cobble, boulder and bedrock; with only a small amount of gravel present (Tab. 1).

\subsection{Glen Ross}

Channel Darter and Round Goby captures were generally associated with moderate water depths $(0.4-0.8 \mathrm{~m})$ and slow to moderate water velocities $\left(0.1-0.5 \mathrm{~ms}^{-1}\right)$, and with gravel and cobble substrates (Tab. 1; Figs. 2 and 3; Figs. S1 and S2). Channel Darter habitat suitability was greatest at water depths between 0.2 and $0.4 \mathrm{~m}$, and water velocities between 0.2 and $0.4 \mathrm{~ms}^{-1}$, and 0.8 and $1.0 \mathrm{~ms}^{-1}$. Suitability declined substantially at depths greater than $0.6 \mathrm{~m}$ and velocities $>0.8 \mathrm{~ms}^{-1}$ (Figs. 2 and 3). Round Goby habitat suitability was greatest at water depths between 0.2 and $0.6 \mathrm{~m}$ and water velocities less 
Table 1. Comparison of mean (standard deviation) habitat measurements at Channel Darter, Logperch and Round Goby collection spots. Available and used microhabitat data were measured at two Trent River locations (September, 2017).

\begin{tabular}{|c|c|c|c|c|c|c|}
\hline & Water depth (m) & Water velocity $\left(\mathrm{ms}^{-1}\right)$ & Bedrock (\%) & Boulder (\%) & Cobble $(\%)$ & Gravel (\%) \\
\hline \multicolumn{7}{|l|}{ Glen Ross } \\
\hline Available $(n=800)$ & $0.45(0.18)$ & $0.35(0.26)$ & $22.4(40.0)$ & $21.6(25.0)$ & $34.1(25.5)$ & $22.0(19.4)$ \\
\hline Channel Darter $(n=119)$ & $0.42(0.18)$ & $0.32(0.22)$ & $2.6(12.9)$ & $22.4(20.9)$ & $47.1(18.0)$ & $27.8(15.3)$ \\
\hline Round Goby $(n=165)$ & $0.38(0.14)$ & $0.31(0.23)$ & $7.7(22.0)$ & $21.1(20.5)$ & $44.2(22.3)$ & $27.0(17.8)$ \\
\hline \multicolumn{7}{|l|}{ Meyers Reach } \\
\hline Available $(n=500)$ & $0.27(0.13)$ & $0.18(0.13)$ & $38.6(45.0)$ & $27.1(25.4)$ & $25.6(25.4)$ & $8.8(10.6)$ \\
\hline Logperch $(n=421)$ & $0.31(0.09)$ & $0.19(0.13)$ & $11.1(22.5)$ & $38.5(20.5)$ & $36.4(21.3)$ & $14.0(9.7)$ \\
\hline Round Goby $(n=195)$ & $0.31(0.08)$ & $0.16(0.10)$ & $23.0(30.6)$ & $21.0(17.7)$ & $39.7(27.2)$ & $16.3(11.6)$ \\
\hline
\end{tabular}
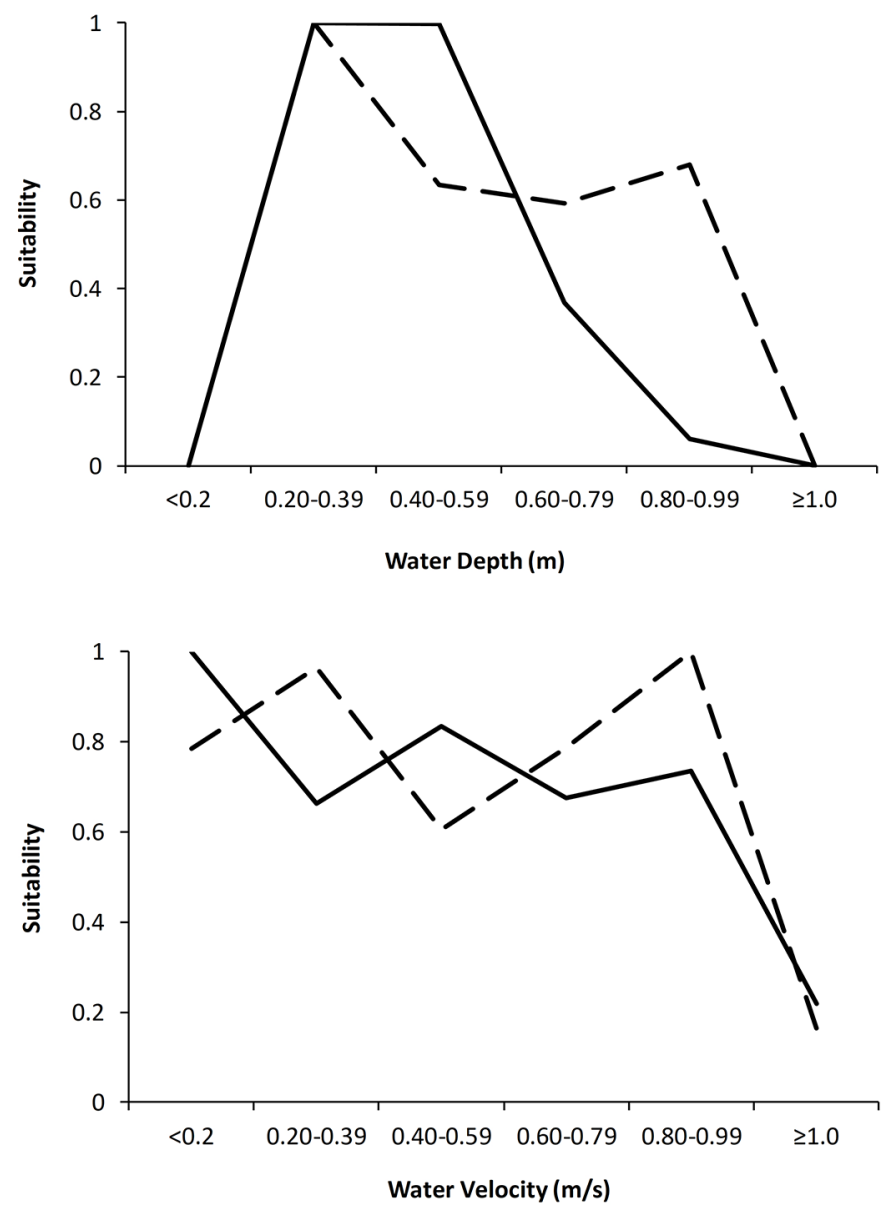

Fig. 2. Estimated Channel Darter (- - ) and Round Goby (solid line) habitat suitability for water depth (upper panel) and water velocity (lower panel) at Glen Ross, based on a resource selection function fitted to habitat use and availability data (Figs. S1 and S2). Suitability is scaled from 0 (unsuitable habitat) to 1 (highly suitable).

than $0.2 \mathrm{~ms}^{-1}$. Suitability declined substantially at depths greater than $0.6 \mathrm{~m}$ and velocities $>0.8 \mathrm{~ms}^{-1}$. For both species, habitat suitability improved as the amount of gravel and cobble increased (Fig. 4).

The first three principal components explained $75.0 \%$ of the total variance among habitat use and availability measure-
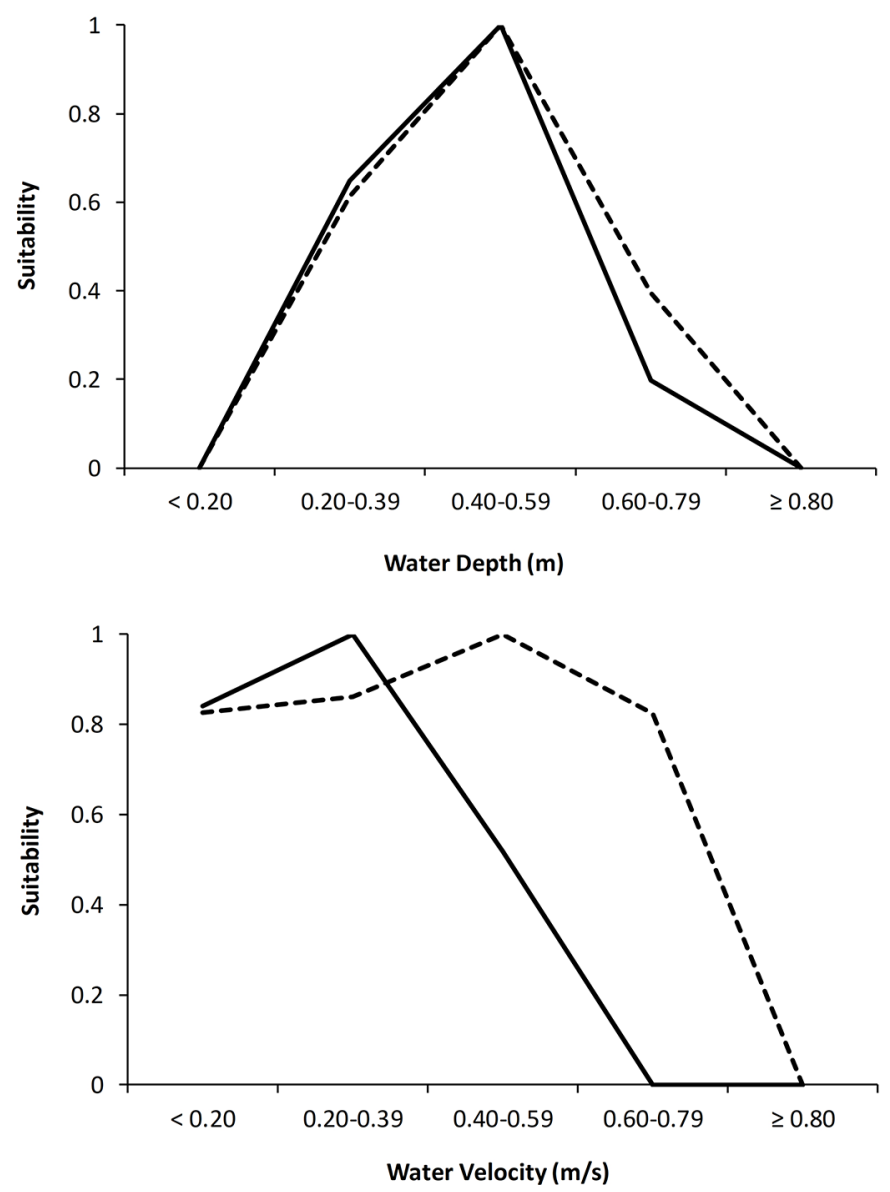

Fig. 3. Estimated Logperch (-) and Round Goby (solid line) habitat suitability for water velocity and water depth at Meyer's Reach, based on a resource selection function fitted to habitat use and availability data (Figs. S1 and S2). Suitability is scaled from 0 (unsuitable habitat) to 1 (highly suitable).

ments at Glen Ross. The first axis (PC1) reflected differences in the amount of gravel, cobble and bedrock at measurement points. Differences in the amount of boulder (PC2), and differences in water velocity and depth measurements (PC3) were represented by the other two axes (Fig. 5). There were significant differences among PC scores associated with 

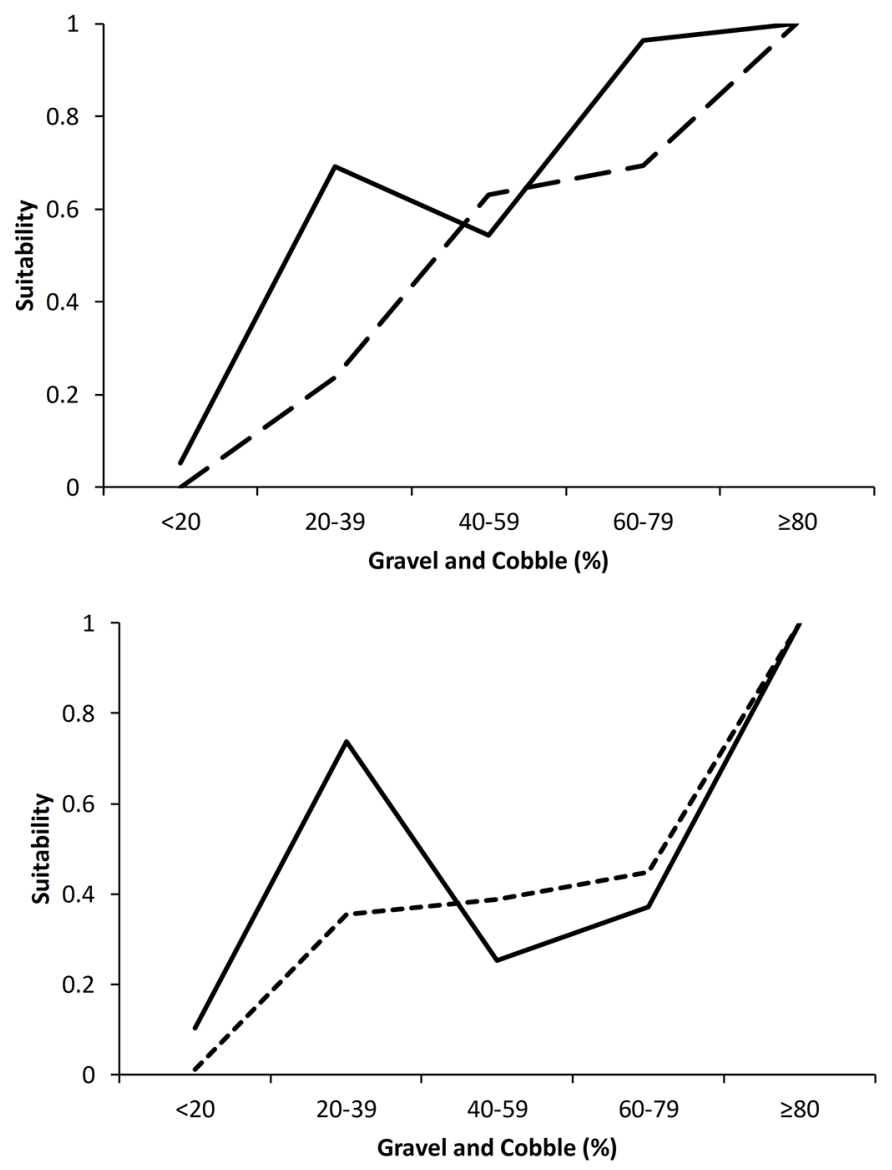

Fig. 4. Estimated Channel Darter (- - ), Logperch (-) and Round Goby (solid line) habitat suitability for gravel and cobble bed material at Glen Ross (upper panel) and Meyer's Reach (lower panel), based on a resource selection function fitted to habitat use and availability data. Suitability is scaled from 0 (unsuitable habitat) to 1 (highly suitable).

available habitat, Channel Darter habitat use, and Round Goby habitat use (MANOVA, Wilk's Lambda: 0.94, $p<0.0001$ ). However, there was no significant difference between Channel Darter and Round Goby PC scores (pairwise comparison Hotelling's $\mathrm{T}^{2}: p>0.45$ ). For both species, habitat use PCA scores were significantly different than available habitat (Hotelling's $\left.\mathrm{T}^{2}: p<0.0001\right)$. Differences among PC 1 scores indicate Channel Darter and Round Goby were both collected from locations with more gravel and cobble, and less bedrock than available across the Glen Ross site (Tab. 1; Fig. 5).

\subsection{Meyer's Reach}

Logperch and Round Goby captures were generally associated with shallow to moderate water depths $(0.2-$ $0.4 \mathrm{~m})$, and slow to moderate water velocities $\left(0.1-0.3 \mathrm{~ms}^{-1}\right)$. At Logperch capture points, there was less bedrock and more boulder than where Round Goby were captured (Tab. 1; Figs. 3 and 4; Figs. S1 and S2). For both Logperch and Round Goby, habitat suitability at Meyer's Reach is predicted be greatest at water depths between 0.2 and $0.4 \mathrm{~m}$ and at locations dominated

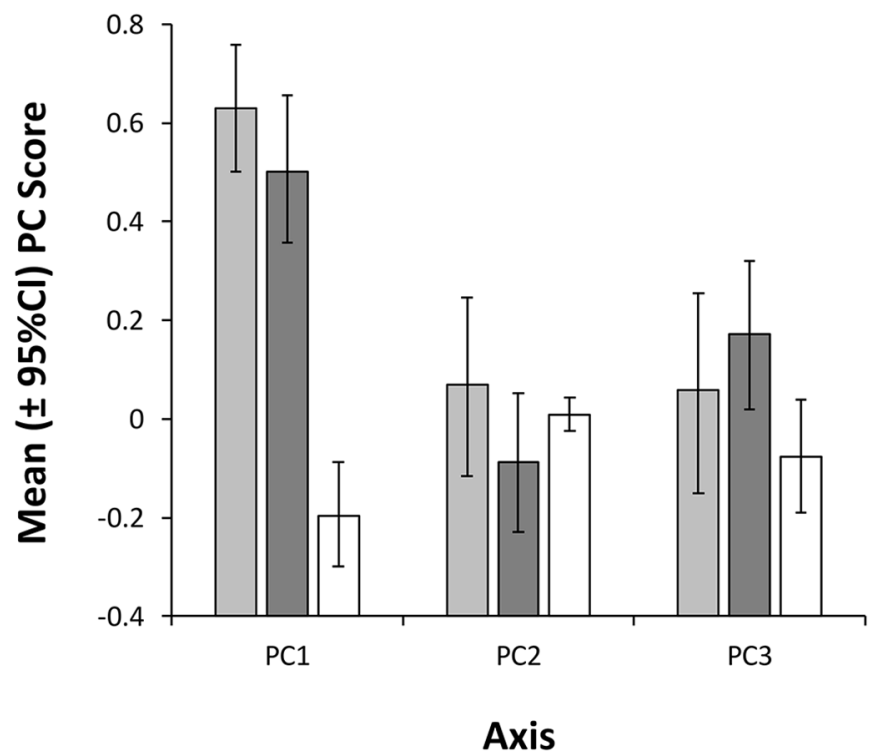

Fig. 5. Comparison of mean ( $95 \%$ confidence interval) PC scores associated with Channel Darter habitat use ( $\square$ ), Round Goby habitat use $(\square)$ and available habitat $(\square)$ at Glen Ross, Trent River. The amount of variation explained by PC1, PC2 and PC3 was 34.4, 21.9 and $18.7 \%$. Dominant PC 1 loadings: bedrock (-0.62), gravel $(0.50)$ and cobble (0.54); dominant PC2 loading: boulder (0.84); and dominant PC3 loadings: water depth $(-0.59)$ and water velocity $(0.70)$.

by gravel and cobble bed material (Figs. 3 and 4). Suitability declined substantially for Round Goby when water velocity was greater than $0.4 \mathrm{~ms}^{-1}$, and for Logperch when water velocity was greater than $0.8 \mathrm{~ms}^{-1}$ (Figs. 3 and 4).

The first three principal components explained $75.1 \%$ of the total variance among habitat habitat use and availability measurements along Meyer's Reach. The first axis (PC1) reflected differences in the amount of gravel, cobble and bedrock. Differences in the amount of boulder (PC2) and water velocity (PC3) were represented by the other 2 axes (Fig. 6). There were significant differences among PC scores associated with available habitat and habitat used by Logperch, and habitat used by Round Goby (MANOVA, Wilk's Lambda: $0.87, p<0.0001)$. There was a significant difference between Logperch and Round Goby habitat use PC scores (Hotelling's $\left.\mathrm{T}^{2}: p<0.0001\right)$. Differences between PC scores from the first 2 axes indicate that Logperch and Round Goby were collected from locations with differing amounts of boulder and bedrock (Tab. 1; Fig. 6). For both species, habitat use PCA scores were significantly different than available habitat (pairwise comparison Hotelling's $\left.\mathrm{T}^{2}: p<0.0001\right)$. Compared to available habitat, both species were collected from spots with less bedrock, and more gravel and cobble.

\section{Discussion}

Past observational and experimental studies have shown that Round Goby affects local habitat use by native smallbodied benthic fishes such as Mottled Sculpin (Dubs and Corkum, 1996; Janssen and Jude, 2001) and Logperch (Balshine et al., 2005; Leino and Mensinger, 2017). 


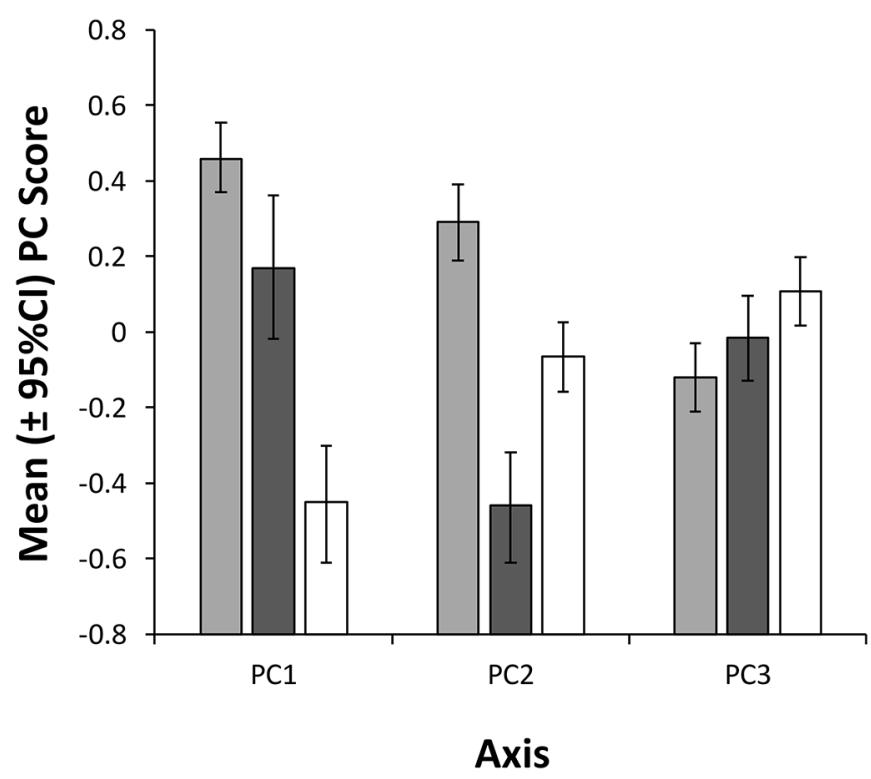

Fig. 6. Comparison of mean ( $95 \%$ confidence interval) PC scores associated with Logperch habitat use ( $\square$ ), Round Goby habitat use ( $\square$ ) and available habitat $(\square)$ at Meyer's Reach, Trent River. The amount of variation explained by PC1, PC2 and PC3 was 39.5, 19.8 and $15.9 \%$. Dominant PC 1 loadings: bedrock $(-0.63)$, gravel $(0.48)$ and cobble (0.43); dominant PC2 loading: boulder (0.73); and dominant PC3 loadings: water velocity (0.88).

Accordingly, competition for space and shelter (such as interstitial spaces between rocks) has been identified as a causal mechanism for native species declines after Round Goby invasions (Burkett and Jude, 2015). At the microhabitat scale, darters are known to segregate spatially based on water depth, water velocity and bed material size (Stauffer et al., 1996; Welsh and Perry, 1998), and non-native darter species have been observed to shift habitat use by native darters (van Snik et al., 2009). Differences in microhabitat use have also been reported between Round Goby and darters (Fantail Darter: Abbett et al., 2013; Logperch: Leino and Mensinger, 2017). In this study, the degree of similarity with Round Goby summer microhabitat differed between the two native darter species studied and, was based on different habitat characteristics.

Habitat differences between Channel Darter and Round Goby were small; largely limited to Channel Darter occupying deeper habitats. In contrast to these results, Abbett et al. (2013) reported Fantail Darter to occupy shallower habitats than Round Goby in a St. Lawrence River tributary (Mullet Creek). The lack of agreement between studies may reflect Trent River habitats being deeper than Mullet Creek, or that Channel Darter typically occupies deeper habitats than Fantail Darter (Stauffer et al., 1996; Reid et al., 2005). Based on past descriptions of Channel Darter habitat use (Reid, 2004; Reid et al., 2005) and practical sampling limitations, habitat use by native darters and the invasive Round Goby was only studied at Trent River habitats of shallow to moderate water depth. Along the Trent River, such wadeable habitats are uncommon as reaches are dominated by deep run habitat and impounded areas. While Channel Darter are known to preferentially use shallow riffle and shoal habitats for most of the year (Etnier and Starnes, 1993; Reid, 2004), Round Goby are easily angled in the summer from deeper habitats along the Trent River (Gutowsky et al., 2011). Therefore, the breadth of microhabitats utilized by Round Goby is expected to be much greater than measured.

There were significant differences between Logperch and Round Goby habitat use; reflective of water velocities and riverbed material selected. As observed in nearby rivers (Reid et al., 2005), Logperch occupied habitats dominated by cobbles and boulders. In experimental studies, Round Goby has been shown to outcompete Logperch for shelter (Balshine et al., 2005) and food resources in rocky habitats (Leino and Mensinger, 2017). While Round Goby has been observed to be more aggressive than native, small-bodied benthic fishes (Dubs and Corkum, 1996), the outcomes of competitions for space and shelter are also size-dependent (Balshine et al., 2005; Groen et al., 2012). Trent River Logperch were on average $20 \mathrm{~mm}$ longer than Round Goby, and therefore, habitat use may be unaffected by the presence of Round Goby.

Habitats occupied by Channel Darter and Logperch differed; along with the degree of habitat overlap with Round Goby. Past studies have found differences between the habitats occupied by the two darter species (Stauffer et al., 1996; Reid et al., 2005). While both species appear to select particular microhabitats, differences among studies are not consistent. In the Trent River, the greater association of Channel Darter with faster and deeper habitats, and more gravels and cobbles, may simply reflect site-level differences in available habitat.

Past research undertaken along the Trent-Severn Waterway on the invasive Round Goby has provided insight into detection and monitoring methods (Gutowsky et al., 2011), rates of expansion (Brownscombe et al., 2012), diet composition (Raby et al., 2010), and variation in behavioural and demographic characteristics along the invasion front (Gutowsky and Fox, 2011; Groen et al., 2012). The length distributions of Round Gobies collected during this study were similar to that measured during the expansion phase of the Trent River invasion, nine years earlier (Gutowsky and Fox 2011). Also, the strong affinity for gravel, cobble and boulder material by Round Goby at Glen Ross and Meyer's Reach was consistent with observations by Brownscombe and Fox (2012) at other Trent-Severn Waterway sites. Round Goby diet in the Trent River includes a variety of invertebrates (zooplankton, amphipods and benthic macroinvertebrates) (Raby et al., 2010; Paton et al., 2019) that are also important prey for Channel Darter and Logperch. Therefore, competition between Round Goby and native darters is potentially occurring for both physical habitat and food resources along the Trent River. While the stomach contents of Logperch and Round Goby collected from the Trent-Severn Waterway have been compared (Paton et al., 2019), diet overlap with Channel Darter has not been studied. Future research on Channel Darter diet and trophic overlap with Round Goby is necessary to provide stronger evidence of resource competition.

Globally, most Round Goby impact studies have been undertaken within a short-time frame ( $<5$ years) after detection (Hirsch et al., 2016). Observations from this study provide a longer-term ( $>10$ years later) perspective on the potential for resource competition with native, small-bodied benthic fishes along the Trent River. In other aquatic habitats, evidence of resource competition has been reported along with 
declines in native fish distribution and abundance (Burkett and Jude, 2015). Documentation of population-level impacts to species such as the Channel Darter that utilize the same microhabitats as Round Goby will, however, require additional field study along the Trent River (e.g. Raab et al., 2018).

\section{Supplementary Material}

Fig. S1. Frequency distributions (percentage of all measurements) for water depth measurements at two Trent River study sites (upper panel: Glen Ross; lower panel: Meyer's Reach), September 2017. Legend abbreviations: Availavailable habitat; $\mathrm{CH}-$ Channel Darter; LG-Logperch; RG-Round Goby.

Fig. S2. Frequency distributions (percentage of all measurements) for water velocity measurements at two Trent River study sites (upper panel: Glen Ross; lower panel: Meyer's Reach), September 2017. Legend abbreviations: Availavailable habitat; $\mathrm{CH}-$ Channel Darter; LG-Logperch; RG-Round Goby.

The Supplementary Material is available at https://www. kmae-journal.org/10.1051/kmae/2019021/olm.

Acknowledgements. Research was supported by Fisheries and Oceans Canada and Ontario Ministry of Natural Resources and Forestry species at risk program funds. I would like to acknowledge the efforts of Sarah Stewart, Matt Sweeting, and Alex Verkuyl who assisted with sampling and data entry. An earlier version of the manuscript was improved by comments from three reviewers.

\section{References}

Abbett R, Wladt EM, Johnson JH, McKenna JE Jr, Dittman DE. 2013. Interactions between invasive Round Gobies (Neogobius melanstomus) and Fantail Darters (Etheostoma flabellare) in a tributary of the St. Lawrence River, New York, USA. J Freshwat Ecol 28: 529-537.

Bain MB, Stevenson NJ. 1999. Aquatic habitat assessment: Common methods. Bethesda, MA: American Fisheries Society, 216 p.

Balshine S, Verma A, Chant V, Theysmeyer T. 2005. Competitive interactions between round gobies and logperch. J Gt Lakes Res 31: 68-77.

Brownscombe JW, Fox MG. 2012. Range expansion dynamics of the invasive Round Goby (Neogobius melanostomus) in a river system. Aquat Ecol 46: 175-189.

Brownscombe JW, Masson L, Beresford DV, Fox MG. 2012. Modeling Round Goby Neogobius melanostomus range expansion in a Canadian river system. Aquat Invasions 7: 537-545.

Burkett E, Jude DJ. 2015. Long-term impacts of invasive Round Goby Neogobius melanostomus on fish community diversity and diets in the St. Clair River, Michigan. J Gt Lakes Res 41: 862-872.

Charlebois PM, Corkum LD, Jude DJ, Knight C. 2001. The Round Goby (Neogobius melanostomus) invasion: Current research and future needs. $J$ Gt Lakes Res 27: 263-266.

Committee on the Status of Endangered Wildlife in Canada (COSEWIC). 2016. COSEWIC assessment and status report on the Channel Darter Percina copelandi, Lake Erie populations, Lake Ontario populations and St. Lawrence populations, in Canada.
Dextrase AJ, Mandrak NE. 2006. Impacts of alien invasive species on freshwater fauna at risk in Canada. Biol Invasions 8: 13-24.

Dubs DOL, Corkum L. 1996. Behavioral interactions between Round Gobies (Neogobius melanostomus) and Mottled Sculpins (Cottus bairdi). J Gt Lakes Res 22: 838-844.

EDDMapS, 2019. Early Detection \& Distribution Mapping System. The University of Georgia-Center for Invasive Species and Ecosystem Health. Available from http://www.eddmaps.org [accessed April 15 2019].

Fisheries and Oceans Canada (DFO). 2011. Recovery Potential Assessment of Eastern Sand Darter (Ammocrypta pellucida) in Canada. Canadian Science Advisory Secretariat Science Advisory Report 2011/020.

Etnier DA, Starnes WC. 1993. The Fishes of Tennessee. Knoxville, TN: University of Tennessee Press, 696 p.

Groen M, Sopinka NM, Marenette JR, Reddon AR, Brownscombe JW, Fox MG, Marsh-Rollo SE, Balshine S. 2012. Is there a role for aggression in Round Goby invasion fronts? Behaviour 149: 685-703.

Gutowsky LFG, Fox MG. 2011. Occupation, body size and sex ratio of Round Goby (Neogobius melanostomus) in established and newly invaded areas of an Ontario river. Hydrobiologia 671: 27-37.

Gutowsky LFG, Brownscombe JW, Fox MG. 2011. Angling to estimate the density of Round Goby (Neogobius melanostomus). Fish Res 108: 228-231.

Hammer Ø, Harper DAT, Ryan PD. 2001. PAST: Paleontological statistics software package for education and data analysis. Palaeontol Electronica 4: 1-9.

Hightower JE, Harris JE, Raabe JK, Brownell P, Drew CA. 2012. A Bayesian habitat suitability model for spawning American Shad in southeastern United States rivers. J Fish Wildlife Manag 3: 184 198.

Hirsch PE, N'Guyen AN, Adrian-Kalchhauser I, Burkhardt-Holm P. 2016. What do we really know about the impacts of one of the 100 worst invaders in Europe? A reality check. Ambio 45: 267-279.

Janssen J, Jude DJ. 2001. Recruitment failure of Mottled Sculpin Cottus bairdi in Calumet Harbor, southern Lake Michigan, induced by the newly introduced Round Goby Neogobius melanostomus. $J$ Gt Lakes Res 27: 319-328.

Johnson JH. 2008. Seasonal habitat use of Brook Trout and juvenile Atlantic Salmon in a tributary of Lake Ontario. Northeast Nat 15: 363-374.

Jude DJ, Reider RH, Smith GR. 1992. Establishment of Gobiidae in the Great Lakes basin. Can J Fish Aquat Sci 49: 416-421.

Kornis MS, Mercado-Silva N, Vander Zanden MJ. 2012. Twenty years of invasion: A review of Round Goby Neogobius melanostomus biology, spread and ecological implications. J Fish Biol 80: 235-285.

Kornis MS, Sharma S, Vander Zanden MJ. 2013. Invasion success and impact of an invasive fish, Round Goby, in Great Lakes tributaries. Divers Distrib 19: 184-198.

Krakowiak PJ, Pennuto CM. 2008. Fish and macrophyte communities in tributary streams of eastern Lake Erie with and without Round Gobies (Neogobius melanostomus, Pallus 1814). J Gt Lakes Res 34: 675-689.

Legendre P, Legendre L. 1998. Numerical Ecology. Second Edition. Amsterdam, NL: Elsevier Science BV, 853 p.

Leidy RA. 1992. Microhabitat selection by the Johnny Darter, Etheostoma nigrum Rafinesque, in a Wyoming stream. Gr Basin Nat 1992: 68-74.

Leino JR, Mensinger AF. 2017. Interspecific competition between the Round Goby, Neogobius melanostomus, and the Logperch, Percina 
caprodes, in the Duluth-Superior harbour. Ecol Freshwat Fish 26: 34-41.

Manly BFJ, McDonald LL, Thomas DL, McDonald TL, Erickson WP. 2002. Resource selection by animals. Statistical design and analysis for field studies. Second edition. Dordrecht, NL: Kluwer Academic Publishers, $221 \mathrm{p}$.

Paton RA, Gobin J, Rooke AC, Fox MG. 2019. Population density contributes to the higher functional response of an invasive fish. Biol Invasions 21: 1737-1749. DOI: 10.1007/s10530-019-01931-z.

Poos M, Dextrase AJ, Schwalb AN, Ackerman JD. 2010. Secondary invasion of the Round Goby into high diversity Great Lakes tributaries and species at risk hotspots: Potential new concerns for endangered freshwater species. Biol Invasions 12: 1269-1284.

Raab D, Mandrak NE, Ricciardi A. 2018. Low-head dams facilitate Round Goby Neogobius melanostomus invasion. Biol Invasions 20: 757-776.

Raby GD, Gutowsky LFG, Fox MG. 2010. Diet composition and consumption rate in Round Goby (Neogobius melanostomus) in its expansion phase in the Trent River, Ontario. Environ Biol Fish 89: 143-150.

Reid SM. 2004. Age-estimates and length distributions of Ontario channel darter (Percina copelandi) populations. J Freshwat Ecol 19: 441-444.

Reid SM. 2006. Distribution and status of river redhorse (Moxostoma carinatum) and channel darter (Percina copelandi) along the TrentSevern Waterway. 2005 Parks Research Forum of Ontario Proceedings, Guelph, Ontario, pp. 221-230.
Reid SM, Mandrak NE. 2008. Historical changes in the distribution of threatened Channel Darter (Percina copelandi) in Lake Erie with general observations on the beach fish assemblage. $J$ Gt Lakes Res 34: 324-333.

Reid SM, Lean J, Carl LM. 2005. Influence of riffle characteristics, surficial geology, and natural barriers on the distribution of the Channel Darter (Percina copelandi) in the Lake Ontario basin. Environ Biol Fish 72: 241-249.

Simonson TD. 1993. Correspondence and relative precision of stream habitat features estimated at two spatial scales. J Freshwat Ecol 8: 363-373.

Stauffer JR Jr, Boltz JM, Kellog KA, van Snik ES. 1996. Microhabitat partitioning in a diverse assemblage of darters in the Allegheny River system. Environ Biol Fish 46: 37-44.

Taraborelli AC, Fox MG, Schaner T, Johnson TB. 2009. Density and habitat use by the Round Goby (Apollonia melanostoma) in the Bay of Quinte, Lake Ontario. J Gt Lakes Res 35: 266-271.

Thomas M, Haas R. 2001. Status of the fisheries in Michigan waters of Lake Erie and Lake St. Clair 2000. Mt. Clemens, Michigan: Michigan Department of Natural Resources, Fisheries Division.

Van Snik GE, Kellogg K, Stauffer J. 2009. Habitat shift of a native darter Etheostoma olmstedi (Teleostei: Percidae) in sympatry with a non-native darter Etheostoma zonale. Amer Midl Nat 154: 166-177.

Welsh SA, Perry SA. 1998. Habitat partitioning in a community of darters in the Elk River, West Virginia. Environ Biol Fish 51: 411-419.

Cite this article as: Reid SM. 2019. Summer microhabitat use and overlap by the invasive Round Goby (Neogobius melanostomus) and native darters in the Trent River (Ontario, Canada). Knowl. Manag. Aquat. Ecosyst., 420, 23. 